\title{
Suburbanisation and commuting modes in the Tallinn metropolitan area
}

\author{
K. Leetmaa, P. Metspalu \& T. Tammaru \\ Institute of Geography, University of Tartu, Estonia
}

\begin{abstract}
Suburbanisation is one of the most important features of spatial population change in Estonia. The aim of this article is to analyse the process of suburbanisation and related changes in commuting modes compared to the late Soviet period in the Tallinn metropolitan area. We use three datasets in our study: individual level 2000 census data, municipal planning documents and a sample survey. The results of the study indicate that most of the people who moved from Tallinn to its suburban areas in the 1990s moved to pre-transition period housing stock. However, the new housing construction is playing an increasingly important role in the suburbanisation process and in the course of time the process has taken the form of uncontrolled urban sprawl lead by the detailed rather than the master plans, and by the interests of real estate development companies. Besides, the sprawl of housing to the former natural and agricultural landscapes has considerably increased the commuters car-dependence compared to the late Soviet period. While public transport was the dominant commuting mode in the Soviet Estonia, today car-based commuting clearly dominates.
\end{abstract}

Keywords: suburbanisation, urban sprawl, commuting modes, Tallinn metropolitan area

\section{Introduction}

Many Eastern and Central European countries witnessed rapid suburbanisation around major cities in the post-socialist period. In Estonia, the increase in the migration from the cities to their surrounding areas took place as well in the 1990s [1] and the process has accelerated remarkably since the second half of the 1990s. The aim of this article is to analyse the trends in suburbanisation, spatial 
patterns of the new residential areas and the modal split of commuters in the Tallinn metropolitan area.

Two key concepts of the study are suburbanisation and urban sprawl. Suburbanisation in the current paper is defined as the population migration from the central cities to their surrounding areas. The term urban sprawl has been considered as a special case of the suburbanisation expressing many negative connotations that the term suburbanisation meets in the literature: e.g. lowdensity land-consuming settlement development, building new housing areas in the "green fields" rather than infilling and extension of existing settlements, cardependence of the new housing areas etc. As the alternative to the sprawl, the smart growth [2] and compact city concepts [3] have been developed in the field literature expressing the normative view that the suburban population growth could take more sustainable and rational forms than the uncontrolled sprawl around the cities.

We study the suburbs of Estonian capital city (Tallinn) metropolitan area. The Tallinn metropolitan area with its 525000 inhabitants $(01.01 .2005)$ is the most populated urban region in the country. Approximately $75 \%$ of its inhabitants live in Tallinn proper today and only $25 \%$ in the suburban municipalities (those rural municipalities and satellite towns around Tallinn proper from where at least $15 \%$ of the workforce commuted to the capital city in the census year 2000). The study is based on three datasets. First, we use individual level anonymous 2000 census data to analyse the suburbanisation process in the $1990 \mathrm{~s}$. The census data enable us to clarify the composition of the people who moved from the Tallinn proper to the suburban municipalities between 1989 and 2000. In addition, the census data include information about the dwelling type choices of the new suburbanites. Second, we use planning documents of the suburban municipalities to analyse the quantity and the location of the new planned residential areas. Thirdly, we use data from a sample survey to analyse the determinants of the modal choice for commuting, focusing on public transport versus car commuting.

\section{Trends and spatial forms of suburbanisation}

The analyses of population trends in the Tallinn metropolitan area reveal the decreasing growth rates for Tallinn and increasing growth rates for the suburbs during the Soviet period (Figure 1). In the 1990s, Tallinn lost a considerable part of its population, while the population of the suburbs stayed stable. However, remarkable inner differences existed within the suburbs (Figure 2). Those municipalities that are bordering with Tallinn witnessed significant population growth. While the municipalities further away from Tallinn suffered from population losses. Satellite towns lost population as well.

All parts of the Tallinn metropolitan area lost population due to the emigration of the Russians back to Russia (Table 1). What regards natural population change and internal migration, the situation was most favourable for the inner circle rural municipalities and for the satellite towns, and least 
favourable for the capital city. Negative net internal migration of the capital city was due to the out-migration of its population into the suburbs in the 1990s.

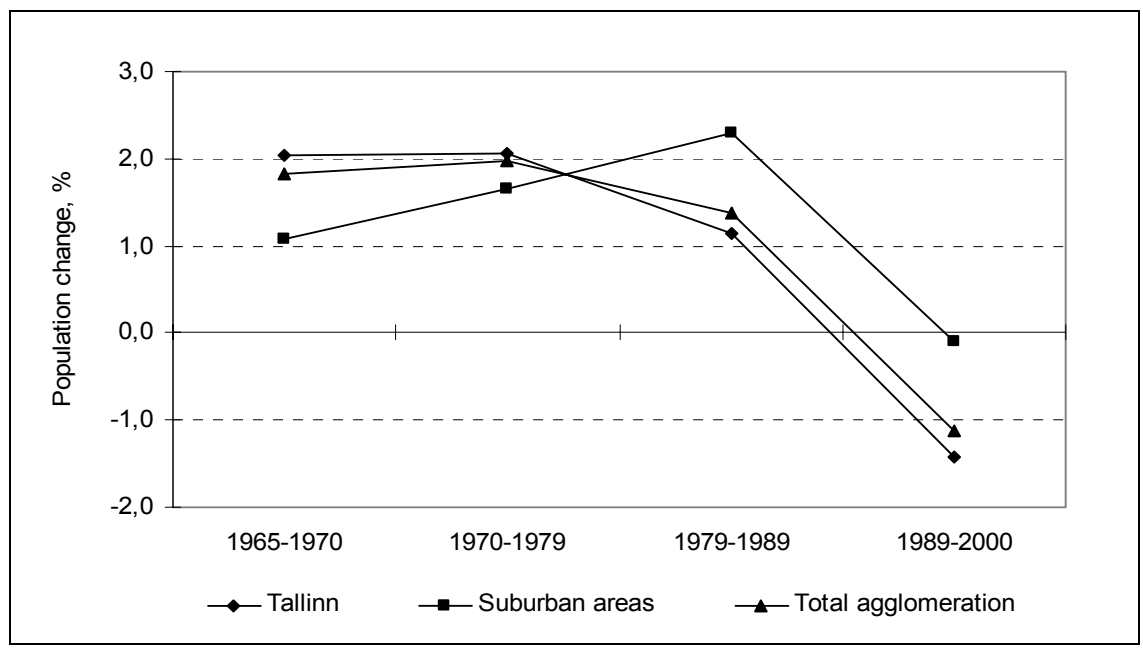

Figure 1: $\quad$ Mid-year population change (\%), 1965-2000 (Estonian Statistical Office).

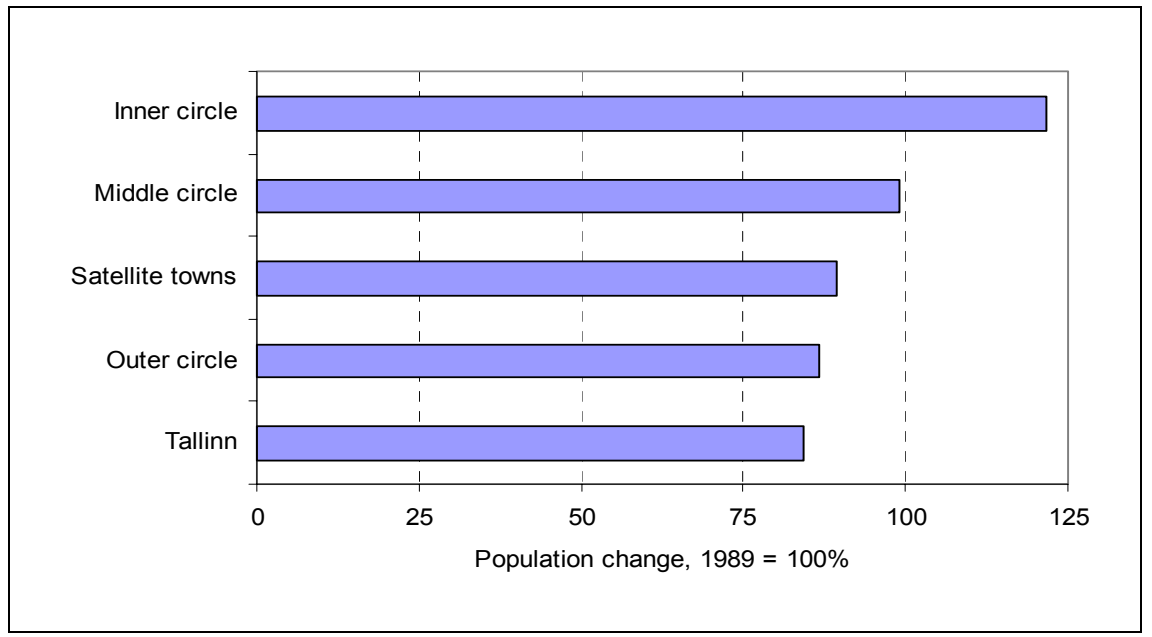

Figure 2: $\quad$ Population change (1989=100\%), 1989-2000 (Estonian Statistical Office).

Let us now take a more detailed look at the spatial outcomes of the suburbanisation phenomenon in the Tallinn region. The post-socialist suburbanisation took quite a compact spatial form. According to the 2000 census data, only one out of five suburbanisers moved to the new single-family houses 
of the 1990s (Table 2). Most of the new suburbanites started to live in the already existing housing stock and the role of the Soviet-time apartment blocks was particularly striking - two out of five suburbanisers chose those houses as their new places of residence. Many people moved into other housing types preceding the transition period: Soviet-time summer home areas around the cities as well as pre-War and Soviet-time single-family houses.

Table 1: $\quad$ Components of population change, 1989-2000 (Estonian Statistical Office).

\begin{tabular}{|l|r|r|r|r|r|r|}
\hline & $\begin{array}{r}\text { Population, } \\
1989\end{array}$ & $\begin{array}{r}\text { Population, } \\
2000\end{array}$ & $\begin{array}{r}\text { Population } \\
\text { change, } \\
1989-2000\end{array}$ & $\begin{array}{r}\text { Natural } \\
\text { change, } \\
1989-2000\end{array}$ & $\begin{array}{r}\text { Net internal } \\
\text { migration, } \\
1989-2000\end{array}$ & $\begin{array}{r}\text { Net external } \\
\text { migration, } \\
1989-2000\end{array}$ \\
\hline Inner circle & 35154 & 42441 & 7287 & 629 & 8125 & -1467 \\
\hline $\begin{array}{l}\text { Middle } \\
\text { circle }\end{array}$ & 15801 & 16181 & 380 & 6 & 2406 & -2032 \\
\hline $\begin{array}{l}\text { Outer } \\
\text { circle }\end{array}$ & 16147 & 14954 & -1193 & -913 & 567 & -847 \\
\hline $\begin{array}{l}\text { Satellite } \\
\text { towns }\end{array}$ & 53945 & 48760 & -5185 & 335 & 5649 & -11169 \\
\hline Tallinn & 478974 & 400378 & -78596 & -14499 & -4228 & -59869 \\
\hline
\end{tabular}

Table 2: $\quad$ Migrants from Tallinn to suburbs by dwelling type (1989-2000).

\begin{tabular}{|l|r|r|}
\hline & Number & Share (\%) \\
\hline Single-family houses & 10859 & 53 \\
\hline New (built in the 1990s) & 4306 & 21 \\
\hline Medium aged (built in the 1960-1980s) & 1721 & 8 \\
\hline Old (built before the 1960s) & 2891 & 14 \\
\hline Summer homes (built in the 1960-1980s) & 1602 & 8 \\
\hline Building time unknown & 341 & 2 \\
\hline Multifamily houses (apartment blocks) & 9108 & 45 \\
\hline New (built in the 1990s) & 981 & 5 \\
\hline Old (built before the 1990s) & 7596 & 37 \\
\hline Building time unknown & 531 & 3 \\
\hline Other/unknown dwelling type & 357 & 2 \\
\hline TOTAL & 20324 & 100 \\
\hline
\end{tabular}

Thus, the suburbanisation process in the 1990s took place in a quite a reasonable and sustainable form - instead of occupying new natural or agricultural areas around the city, the existing settlement structure was used by the new suburban population. However, this was neither the concious policy of the institutions responsible for the regional planning nor the concious choise by the suburbanisers. Moreover, the modern democratic planning principles only started to institutionalise since about 1995 when the first planning law was established in Estonia. The explanation rather derives from the socio-economic conditions of the time. Many people were not able to adapt to the new economic circumstances and were faced with the problems of coping in the cities. In addition, there was a great deal of relatively cheaper housing available in the suburban areas, e.g. big apartment blocks were the emigrated Russians lived before and former summer homes, that could be rebuilt for permanent living. And last but not least, there was no mortgage market available yet. All these 
factors limited new housing construction, especially at the beginning of the decade. Therefore, the suburbanisation in the early transition years rather reflected the situation where the composition of potential out-migrants from the city matched well with the available housing stock in the suburban municipalities. This illustrates the rule that the suburban housing market has direct influence on the forms that the suburbanisation process takes in the region. The lack of suitable housing in the suburban areas could have lead to the migration to the areas futher away from the capital city like it happened for example in Hungary [4].

This principle also partly explains the recent turn in the suburbanisation process from the situation when people moved to already existing dwellings in the most of the 1990s to the situation in the 2000s when more and more people choose the new detached and multifamily houses as their destinations outside the city [5]. Parallel to the increase in wealth in Estonia the trends in housing are increasingly influenced by the pressure from the real estate development and financial sector. The tight competition in these sectors makes it possible to find a new suburban "dream-home" with a reasonable price and the alternative dwellings (existing housing stock) is concidered less likely.

The study of the planning documents of the suburban municipalities confirms the turnaround in the spatial forms of suburbanisation. The number of detailed plans designing new residential areas in the suburbs has increased considerably during the period of 1995 to 2004. Summing up all prognoses of new housing in the suburban municipalities, 20.640 new dwellings were planned already by the year 2004 in the suburban municipalities, vast majority of it (83\%) as the singlefamily houses. Besides, according to the prognoses of municipalities, about 8800 former summer homes will be rebuilt for permanent living in the future. This would create almost 30.000 new dwellings for potential new suburban population in the time span of about 10 to 15 years. Very rough calculation (if average suburban household size would be 3 persons) shows that it could make more than one fifth of the population in the city of Tallinn today, which clearly refers to the ongoing over-planning. This argument is enforced by the fact that there was about threefold difference between the number of actual building permits and the number of planned dwellings according to the enforced detailed plans at the same period (1995-2004).

This indicates that there is a lack of strategic comprehensive planning initiatives in the Tallinn urban region. As a matter of fact the basic tools for stimulating urban containment and for regulating spatial planning in general have been written also into the Estonian planning legislation similar to many other European countries, but their implementation in practice is poor. It appears that the detailed plans are acquiring the role of the superior comprehensive plans and these are used by the interested parties with the purpose "to book" the right to develop a piece of land in the future. In fact, in 2003, by the time when the real estate development boom had started already in Estonia, nearly half of the suburban municipalities had not yet elaborated their master plans, i.e. a holistic strategic vision for the development of their territory. This has considerably 
helped the planning practice to incline in favour of the real estate development sector and landowners.

The tradeoff between the planning legislation and actual planning practice driven by the real estate sector in Estonia becomes strikingly evident when analysing the content of the detailed plans. For example, $73 \%$ of the new residental areas designed by detailed plans are located in greenfield land (Figure 3) and are loosely connected to the existing settlement patterns. Such a haphazard development of rural lands has often been considered as a key feature of urban sprawl.

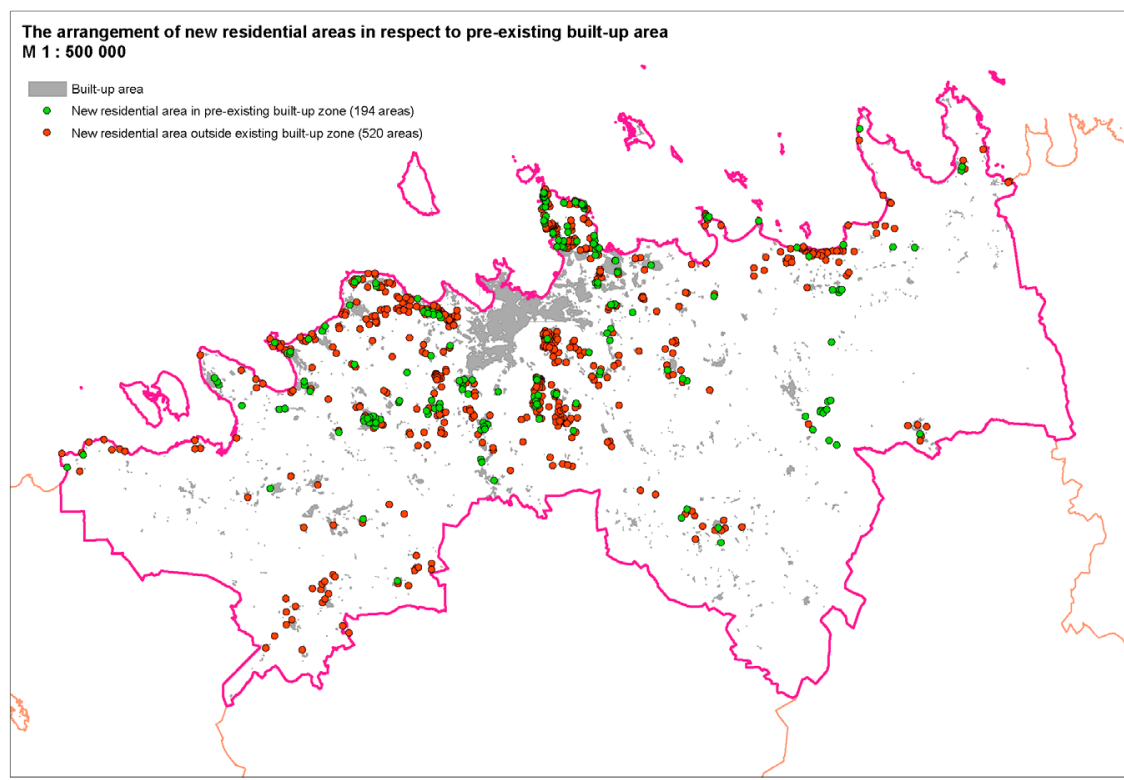

Figure 3: Existing and planned residential areas, 1995-2005.

Most of the detailed plans (69\%) contain neither the planned public space nor the primary services that should necessarily belong to the high-standard residential environment. This means that only a single "bedroom"-function is planned for the new residential areas, which is considered as a typical early stage of suburbanisation in the literature [6]. Such planning principles, however, do not originate from specific zoning laws as it has been the case in the United States. The creation of monofunctional areas is rather related to the interests of the private developers, who want to gain profit as fast and as quickly as possible. Since the old housing stock predating transition period does not meet contemporary requirements, it is still possible to sell new houses without making any investments into the surrounding social infrastructure.

Such a "trend-planning" [7], where the whole planning process is lead by market forces, could only be balanced with strengthening the municipal and 
regional planning system. In fact, guiding the spatial trends in the region through the haphazard decisions about the small pieces of land will never contribute to the development of sustainable urban forms. Only the comprehensive strategic decisions about the allocation of the social and physical infrastructure and, therefore, the allocation of municipal and regional resources, could bear this role.

\section{Commuting modes of the suburbanisers}

An important dimension of sustainable urban development, especially in the context of suburbanisation, is related to transport and commuting. The sprawl of housing to the former natural and agricultural landscapes has brought along a dramatic or four-time increase in the number of commuters from the suburbs to Tallinn [8]. Next we will focus on the availability of public transport and the actual modal split between public and private transport among commuters. It becomes evident that the planned residential areas are quite close to the existing public transport routes and stops (Figure 4). However, it does not necessarily mean sufficient quality of public transport in the region.

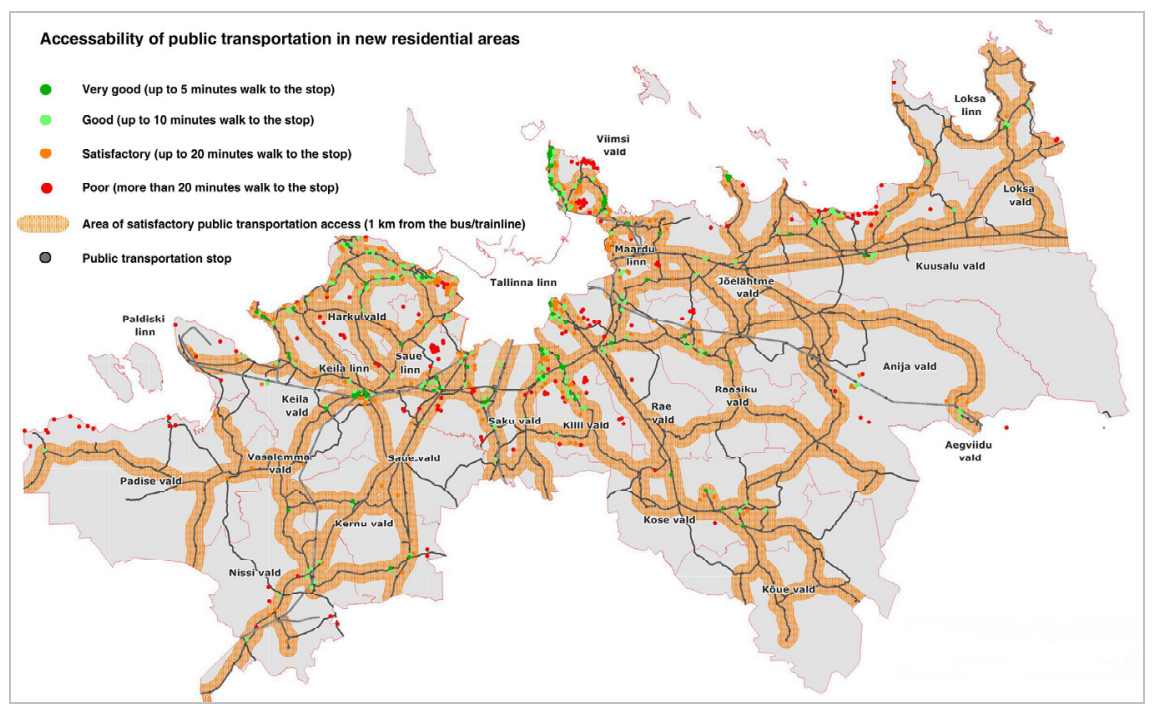

Figure 4: Accessibility of public transport in the new residential areas.

Our study indicates that the commuting modes have changed considerably compared to the late Soviet period. At this time, public transport including the one organised by enterprises themselves, was very important, while today, carbased commuting is of utmost significance. The change to car-based commuting is dramatic. In 1982, only $14 \%$ of commuters used a car in the Tallinn metropolitan area [9], which was similar to the average of the Soviet Union [10]. Today about $60 \%$ or 19.000 of all commuters use a car as the main mean of transport for traveling between home and work in the Tallinn metropolitan area 
[7]. 15.000 of the 22.000 commuters from Tallinn to suburbs use a car, which is more than the total number of commuters between Tallinn and suburbs (13.000) in the late Soviet years. About half of the car-commuters live in the nearby inner circle municipalities of Tallinn. Although this means that the travel distances are not long, it brings along congestions in the capital city. The increased car ownership has made the considerable increase in car-commuting possible and alongside with this also the public transport system is inefficient (the frequency is not sufficient, busses and trains are not comfortable etc).

Table 3: Determinants of commuting mode for commuters from suburbs-toTallinn (public transport $=1$, car $=0$ ).

\begin{tabular}{|c|c|c|c|c|}
\hline & & $\mathrm{B}$ & $\operatorname{Exp}(B)$ & Sig. \\
\hline $\begin{array}{l}\text { Gender } \\
\text { (Reference: Male) }\end{array}$ & Female & 1,961 & 7,105 &, 000 \\
\hline $\begin{array}{l}\text { Age } \\
\text { (Reference: } 30-39 \text { ) }\end{array}$ & $\begin{array}{r}20-29 \\
40-49 \\
50+\end{array}$ & $\begin{array}{l}, 024 \\
, 435 \\
, 760 \\
\end{array}$ & $\begin{array}{l}1,025 \\
1,545 \\
2,139 \\
\end{array}$ & $\begin{array}{l}, 936 \\
, 143 \\
, 022 \\
\end{array}$ \\
\hline $\begin{array}{l}\text { Ethnic origin } \\
\text { (Reference: Estonians) }\end{array}$ & Minorities & ,227 & 1,255 &, 511 \\
\hline $\begin{array}{l}\text { Household size } \\
\text { (Reference: } 2 \text { members) }\end{array}$ & $\begin{array}{r}1 \text { member } \\
3+\text { members }\end{array}$ & $\begin{array}{r}, 993 \\
-, 279 \\
\end{array}$ & $\begin{array}{r}2,698 \\
, 757\end{array}$ & $\begin{array}{l}, 111 \\
, 212 \\
\end{array}$ \\
\hline $\begin{array}{l}\text { Education } \\
\text { (Reference: Secondary) }\end{array}$ & $\begin{array}{r}\text { Primary } \\
\text { University } \\
\text { Vocational } \\
\end{array}$ & $\begin{array}{l}-, 188 \\
-, 090 \\
-, 137 \\
\end{array}$ & $\begin{array}{l}, 828 \\
, 914 \\
, 872 \\
\end{array}$ & $\begin{array}{l}, 708 \\
, 789 \\
, 615 \\
\end{array}$ \\
\hline $\begin{array}{l}\text { Occupation } \\
\text { (Reference: Specialist) }\end{array}$ & $\begin{array}{r}\text { Manager } \\
\text { Clerk } \\
\text { Skilled worker } \\
\text { Unskilled worker } \\
\end{array}$ & $\begin{array}{r}-, 223 \\
, 685 \\
, 895 \\
1,730 \\
\end{array}$ & $\begin{array}{r}, 800 \\
1,983 \\
2,447 \\
5,638 \\
\end{array}$ & $\begin{array}{l}, 660 \\
, 021 \\
, 010 \\
, 000 \\
\end{array}$ \\
\hline $\begin{array}{l}\text { Income per household member } \\
\text { (Reference: } 3000-3999 \mathrm{EEK} / \text { month) }\end{array}$ & $\begin{array}{l}\text { Less than } 3000 \\
4000 \text { and more }\end{array}$ & $\begin{array}{l}-, 381 \\
-, 871\end{array}$ & $\begin{array}{l}, 683 \\
, 419\end{array}$ & $\begin{array}{l}, 171 \\
, 005 \\
\end{array}$ \\
\hline $\begin{array}{l}\text { Municipality distance from Tallinn } \\
\text { (Reference: Nearby/Bordering) }\end{array}$ & $\begin{array}{r}\text { Mid-range } \\
\text { Distant }\end{array}$ & $\begin{array}{l}, 237 \\
, 225 \\
\end{array}$ & $\begin{array}{l}1,268 \\
1,253\end{array}$ & $\begin{array}{l}474 \\
4,492 \\
\end{array}$ \\
\hline $\begin{array}{l}\text { Municipality type } \\
\text { (Reference: Rural) }\end{array}$ & Urban & ,812 & 2,253 & ,004 \\
\hline $\begin{array}{l}\mathrm{N}=590 \\
\text { Constant }\end{array}$ & & $-2,761$ & ,063 &, 000 \\
\hline
\end{tabular}

The analysis of the commuting modes of commuters by main personal and location related characteristics (Table 3) brings up the following results. Female and older people have the highest probabilities to use public transport (bus, train). Ethnic origin, household size and education do not produce statistically significant differences in commuting modes. People working in higher positions and earning higher incomes prefer the car to public transport. Finally, distance from Tallinn does not have an impact on modal split, while people living in densely populated urban municipalities (satellite towns) have a higher probability to use public transport than the people who live in more sparsely populated rural communities. Thus, compact forms of settlement, independent of 
distance and major personal characteristics, favour a choice for public transport. In the opposite, living in rural areas, where, as we demonstrated above, most of the new planning initiative takes place, increases the probability to opt for cars despite the fact that these settlements are not located too far away from the regular public transport routes.

\section{Conclusions}

Our study proved that the 1990s in the Tallinn metropolitan area can be labeled as the transition period from the compact form of settlement structure to the more fragmented settlement pattern in the 2000s. Although the migration motives under the Soviet regime were quite different from the motives prevailing in the transition period we can argue that the main spatial features of settlement development were similar in these two periods. In the Soviet years concentrated rather than dispersed settlements emerged around the city, e.g. industrial sattelite towns or centres of agricultural collective farms. Suburbanisation in the early transition years was based on that legacy and on the special conditions of postsocialist transition period: emigration of Russian population left a considerable amount of dwellings free for potential suburbanisers; restitution of land opened up the opportunity to live in countryside, but even more importantly the opportunity to sell the restituted land for real estate development purposes; coping problems typical to the transition period "pushed" many people out of the city to look for cheaper dwellings in the suburbs etc.

From the late 1990s onwards the suburbanisation process in the Tallinn metropolitan area has been taking more and more the form of uncontrolled sprawl. Overall increase in wealth and cheap mortgages are the main general factors encouraging this rapid sprawl. The proportion of the suburbanisers who choose to move in a new house is increasing and, at the same time, the capacity of the local governments to steer this development pressure is weak. As a result, the planning practice in the Tallinn metropolitan area is guided by the tight competition of the real estate development and financial sector. Although the Estonian legislation proposes to plan the suburban land-use through regional and municipal planning initiatives, in reality an plot by plot land-use design is taking place. In this way the interests of the community and the region, as for example plannig the infrastructure together with the new residential areas, remain on the background. Moreover, because of such a haphazard development nobody in fact has a thorough overview, which could be the gross spatial influences of the process.

As an example, the analysis of choices for commuting modes indicated us that the public transport network in the capital city region of Estonia is not functioning properly. What concerns the accessibility of the new residential areas to the main public transport routes and stops the public transport network seems to be adequate. Nevertheless, there has been a dramatic growth in car-commuting during the post-socialist years. It seems that today public transport is able to offer a reasonable alternative to car-commuting in the suburban satellite towns only, while most of the new residential development takes place in rural areas. 


\section{References}

[1] Tammaru, T., Kulu, H. \& Kask, I., Urbanisation, Suburbanisation and Counterurbanisation in Estonia. Eurasian Geography and Economics, 45(3), pp. 159-176, 2004.

[2] Danielsen, K. A., Lang, R. E. \& Fulton, W., Retracting Suburbia: Smart Growth and the Future of Housing. Policy Debate 10(3), pp. 512-540, Fannie Mae Foundation, 1999.

[3] Jenks, M., Burton, E. \& Williams, K., The Compact City: A Sustainable Urban Form? E\&FN Spon: London, 1996.

[4] Ladányi, J. \& Szelényi, I., Class, Ethnicity and Urban Restructuring in Postcommunist Hungary. Social Change and Urban Restructuring in Central Europe, ed. G. Enyedi, Akadémiai Kiadó: Budapest, pp. 67-86, 1998.

[5] Raagmaa, G. \& Kliimask, J., Keskus-ääremaa lained Eesti elamuehituses [Centre-periphery waves in housing construction in Estonia]. Asustus ja ränne Eestis. Uurimusi Ann Marksoo 75. sünnipäevaks, ed. H. Kulu. \& T. Tammaru, Tartu University Press: Tartu, pp. 82-116, 2005.

[6] Hartshorn, T. A. \& Muller, P. O., Suburban Downtowns and the Transformation of Metropolitan Atlanta's Business Landscape'. Urban Geography, 10(4), pp. 375-395, 1989.

[7] Brindley, T., Rydin, Y. \& Stoker, G., Remaking Planning. The politics of Urban Change, Pergamon Press: Oxford, 1996.

[8] Tammaru, T. Suburbanisation, Employment change, and Commuting in the Tallinn Metropolitan Area. Environment and Planning A, 37(9), pp. 1669-1687, 2005.

[9] Marksoo, A., Kaljulaid, H., Kask, I., Kaup, U., Rull, K., Rõivas, T. Töojõo territoriaalse mobiilsuse seaduspärasused Eesti NSVS [Regularities of territorial mobility of labour in Estonian SSR], unpublished applied research project, grant T-045, Institute of Geography, University of Tartu: Tartu, 1983.

[10] Fuchs, R. \& Demko, G. The Postwar Mobility Transition in Eastern Europe. Geographical Review, 68, pp. 171-182, 1978. 